\title{
Effects of a propionic acid-based preservative on storage characteristics, nutritive value, and energy content for alfalfa hays packaged in large round bales ${ }^{1}$
}

\author{
W. K. Coblentz ${ }^{* 2}$ and M. G. Bertram† \\ *USDA-ARS, US Dairy Forage Research Center, Marshfield, WI 54449 \\ †Superintendent, University of Wisconsin Marshfield Agricultural Research Station, Marshfield, WI 54449
}

\begin{abstract}
During 2009 and 2010, alfalfa (Medicago sativa L.) hays from 2 cuttings harvested from the same field site were used to evaluate the effects of a propionic acidbased preservative on the storage characteristics and nutritive value of hays stored as large round bales. A total of 87 large round bales (diameter $=1.5 \mathrm{~m}$ ) were included in the study; of these, 45 bales served as controls, whereas 42 were treated with a commercial propionic acid-based preservative at mean application rates of $0.5 \pm 0.14$ and $0.7 \pm 0.19 \%$ of bale weight, expressed on a wet (as is) or dry matter basis, respectively. Initial bale moisture concentrations ranged from 10.2 to $40.4 \%$. Internal bale temperatures were monitored daily during an outdoor storage period, and heating characteristics were summarized for each bale as heating degree days (HDD) $>30^{\circ} \mathrm{C}$. For acid-treated bales, the regression relationship between HDD and initial bale moisture was best fitted to a quadratic model in which the linear term was dropped to improve fit $\left(\mathrm{Y}=2.02 \mathrm{x}^{2}-401 ; \mathrm{R}^{2}\right.$ $=0.77$ ); control hays were best fitted to a nonlinear model in which the independent variable was squared $\left[\mathrm{Y}=4,112-\left(4,549 \times \mathrm{e}^{-0.000559 \mathrm{x}^{*} \mathrm{x}}\right) ; \mathrm{R}^{2}=0.77\right]$. Based on these regressions, acid-treated bales accumulated more HDD than control hays when the initial bale moisture was $>27.7 \%$; this occurred largely because acid treatment tended to prolong active heating relative to control hays. Linear regressions of recoveries of dry matter on HDD did not differ on the basis of treatment, yielding a common linear relationship of $\mathrm{Y}=-0.0066 \mathrm{x}+96.3$ $\left(\mathrm{R}^{2}=0.75\right)$. Regressions relating changes (post-storage - pre-storage) in concentrations of several nutritional components (neutral detergent fiber, lignin, ash, crude protein, and total digestible nutrients) with HDD for

\footnotetext{
Accepted September 16, 2011.

${ }^{1}$ Mention of trade names or commercial products in this article is

${ }^{2}$ Corresponding author: wayne.coblentz@ars.usda.gov
}

Received April 28, 2011. solely for the purpose of providing specific information, and does not imply either recommendation or endorsement by the US Department of Agriculture.
\end{abstract}

acid-treated hays typically exhibited more inflection points or were higher-ordered polynomial regressions than those of control hays. These more complex responses probably reflected the perturbation of normal heating patterns following acid treatment; however, overall effects on post-storage nutritive value were relatively limited in scope. The potential to improve nutritive value relative to cost for these large round bales was not especially favorable, and hay producers may find that diligence to achieve adequate field desiccation before baling, or use of oxygen-exclusion methods, such as wrapping in plastic, may be better alternatives for preserving moist hays.

Key words: alfalfa hay, heat damage, preservative, heating

\section{INTRODUCTION}

Recent research (Coblentz and Hoffman, 2009a) has demonstrated that alfalfa (Medicago sativa L.) hay packaged in large round bales is particularly sensitive to heating, DM losses, and other deleterious changes in various constituents comprising forage fiber (Coblentz and Hoffman, 2009b), protein (Coblentz et al., 2010), and energy density (Coblentz and Hoffman, 2010). It is well known that these processes are initiated primarily through respiration of microorganisms associated with the hay, thereby respiring plant DM (primarily sugars) into $\mathrm{CO}_{2}$, water, and heat. Furthermore, the magnitude of heating responses in large round bales is positively related to bale diameter. This becomes an important dilemma for hay and livestock producers because the cost and availability of labor has necessitated the adoption of large round or large square hay packages on many farms. Although the threshold bale moisture for satisfactory storage of traditional $(45-\mathrm{kg})$ small square bales has been established for decades (20\%; Collins et al., 1987), this threshold is not appropriate for larger bales weighing $500 \mathrm{~kg}$ or more. Coblentz and Hoffman (2009a) demonstrated that the relationship between heating degree days (HDD), an index integrating the magnitude and duration of heating during bale stor- 
age, and initial bale moisture was both positive and linear for alfalfa-orchardgrass hays packaged in 0.9- and $1.2-\mathrm{m}$ diameter round bales. When bale diameter was increased to $1.5 \mathrm{~m}$, the relationship between HDD and initial bale moisture remained positively associated, but accumulation of HDD was accelerated per unit of initial bale moisture $\left[\mathrm{Y}=0.99 \mathrm{x}^{2}-82\right]$. Therefore, as hay is packaged in larger bale sizes, the need for proactive action to decrease or eliminate heating becomes increasingly important. In addition, unstable weather, poor drying conditions, or unpredictable rainfall events often place valuable hay crops at risk. These interrelated factors often force producers to choose between subjecting their hay crops to rain damage, or baling at moisture concentrations too great for safe storage.

To combat these problems, various formulations of organic acids have been marketed as preservatives, most specifically for hays that could not be field desiccated to DM concentrations great enough to naturally decrease heating. Currently, these preservatives are primarily propionic acid-based products that often are buffered to limit oxidative damage to expensive farm equipment. In the past, several studies (Sheaffer and Clark, 1975; Rotz et al., 1991; Buckmaster and Heinrichs, 1993) have evaluated propionic acid-based products applied to small rectangular bales with some success. More recently, Shinners (2000) evaluated a propionic acid preservative for large square bales of alfalfa packaged over a relatively wide moisture range. Bales treated with propionic acid maintained greater moisture concentrations during storage, which may have sustained microbial activity relative to controls. Previously, Rotz et al. (1991) associated this response with the hygroscopic nature of propionic acid, and reported that moisture concentrations in acid-treated hay may remain up to 7 percentage units greater than controls, even after 6 mo of storage. As a result of these factors, it often has been difficult to associate improvements in DM retention with acid treatment (Rotz et al., 1991; Shinners, 2000); however, measurable improvements relative to moist control hays may be observed after only a month in storage (Rotz et al., 1991). These research efforts generally have not been extrapolated to include large round bales weighing 500 $\mathrm{kg}$ or more. Our objective was to conduct an extensive evaluation of the effects of a commercial propionic acidbased preservative on the subsequent storage characteristics, nutritive value, and energy density of alfalfa hays packaged in 1.5-m large round bales.

\section{MATERIALS AND METHODS}

\section{Field Management}

Source of Hays. This project included 2 independent hay harvests obtained during the 2009 and 2010 growing seasons from the same 16.2-ha field site located on the University of Wisconsin Marshfield Agricultural Research Station, near Stratford $\left(44^{\circ} 7^{\prime} \mathrm{N}, 90^{\circ} 1^{\prime} \mathrm{W}\right)$. The soil type at this location was a Withee silt loam (fineloamy, mixed, frigid, Aeric Glossaqualfs). Previously, Pioneer 53V52 alfalfa (Pioneer Hi-Bred International Inc., Johnston, IA) was no-till drilled into residual stubble from a previous crop of cereal rye (Secale cereale L.) at a rate of $18 \mathrm{~kg} /$ ha on June 4, 2008. A total of 87 bales were produced for the project; these included 53 bales from the first cutting during 2009 (moisture range $=17.8$ to $40.4 \%$; harvest 1 ) and 34 bales from the third cutting of 2010 (moisture range $=10.2$ to $38.9 \%$; harvest 2).

Harvest 1. Standing alfalfa forage was mowed in wide (2-m) swaths at the early bloom stage of growth at $1300 \mathrm{~h}$ on 1 June 2009 with a Case-International mower-conditioner (Model 8830; J. I. Case Co., Racine, WI). Subsequently, forage was allowed to wilt until $1000 \mathrm{~h}$ on 4 June (69 h post-mowing) when adjacent windrows were raked into double, but not overlapped, rows with a side-delivery rake. Beginning at $1300 \mathrm{~h}$ on the same day (72 h post-mowing), bales were made either with or without a commercial propionic acid-based preservative (FRESH CUT Plus; Kemin AgriFoods North America Inc., Des Moines, IA). All hay was baled with a Ford-New Holland round baler (Model BR 740A; CNH America LLC, Racine, WI), and each bale was tied with 2 revolutions of net wrap. The preservative was applied at the baler intake with a commercial spray applicator (Model 442; Harvest Tec Inc., Hudson, WI) mounted above the pick-up assembly on the baler. Generally, bales were made in sets, requiring at least 7 bales. Three control (no preservative) bales were made initially to establish an estimate of average bale weight and baling time; these were then followed by 3 bales made with the acid preservative. For acid-treated hays, the actual amount of preservative delivered per bale was calculated from the product of the calibrated acid application rate $(\mathrm{kg} / \mathrm{s})$ and the mean baling time (s/bale). After producing 3 acid-treated bales, an additional control bale was produced that served as a clean-out bale to remove any residual acid from the baler before the next set of control bales was made. Clean-out bales were discarded, and no data from those bales were included in the experiment. As forage dried, sets of bales were made at intervals ranging from 0.50 to $0.75 \mathrm{~h}$ between 1300 to $1800 \mathrm{~h}$ on 4 June. Additional groups of bales were made similarly at 1500 and 1700 $\mathrm{h}$ on 5 June (98 and $100 \mathrm{~h}$ post-mowing), as well as at $1700 \mathrm{~h}$ on 12 June ( $268 \mathrm{~h}$ post-mowing). The last set of bales received multiple rainfall events totaling 51 $\mathrm{mm}$ of precipitation before baling. Data from this last set of rain-damaged bales were included in the analy- 
sis of HDD and DM recovery, but were omitted from analysis of forage nutritive value because nutritional components varied substantially following rainfall events. For these acid-treated rain-damaged bales $(\mathrm{n}=$ 4), maximum internal bale temperature $(\mathbf{M A X})=72.1$ $\pm 2.17^{\circ} \mathrm{C}, \mathrm{HDD}=562 \pm 262.9$ and $\mathrm{DM}$ recovery $=90.7$ $\pm 2.06 \%$, whereas for corresponding control hays $(\mathrm{n}=$ $3)$, MAX $=64.7 \pm 10.59^{\circ} \mathrm{C}, \mathrm{HDD}=595 \pm 568.6$, and DM recovery $=90.6 \pm 3.14 \%$.

Harvest 2. At 1000 h on 25 August 2010, the third cutting of alfalfa from the same field site described for harvest 1 was mowed and conditioned at the first-flower stage of growth as described previously. The mowed and conditioned forage was allowed to wilt in wide swaths until $1030 \mathrm{~h}$ on 27 August (48.5 h post-mowing). At that time, it was raked into double windrows with a sidedelivery rake. Beginning at $1200 \mathrm{~h}$ the same day $(50 \mathrm{~h}$ post-mowing), bales were generated with generally the same procedures described for harvest 1 , concluding at approximately $1700 \mathrm{~h}$. Two further sets of bales were produced on August 30 ( $\geq 102 \mathrm{~h}$ post-mowing), again using similar field procedures. One difference in field procedures between harvests 1 and 2 was that an in-line flow meter was used for harvest 2 to measure the actual amount of acid applied to each bale. This procedural adjustment was added to allow more accurate and precise determination of actual acid application rates. Averaged across 2009 and 2010, the mean application rate (\% of bale weight) of acid preservative across all bales was $0.5 \pm 0.14 \%$ (as is basis) or $0.7 \pm 0.19 \%$ (DM basis).

Pre-Storage Sampling and Processing. Immediately after packaging, all bales were weighed to the nearest $0.90-\mathrm{kg}$ increment on a motorized feed cart equipped with load cells, and then placed on wooden pallets located outdoors over a gravel-based drive alley. Wooden pallets were positioned approximately $2 \mathrm{~m}$ apart to allow for good air movement around the bales, and to permit sunlight to have unrestricted penetration to the soil surface. Bale width and diameter were determined with a tape measure, thereby allowing subsequent calculation of bale volume and DM density. Bale diameter was measured from 3 orientations (horizontal, diagonal, and vertical) across one end of each bale; the mean of these diameter measurements then was used to calculate bale volume. All bales were sampled initially with nine $0.61-\mathrm{m}$ deep core samples $(0.025-\mathrm{m}$ diameter) that were taken from the circumferential surface of one side of each bale using a Uni-Forage Sampler (Star Quality Samplers, Edmonton, AB, Canada). The 9 initial core samples were taken from a 3 (vertical) $\times 3$ (horizontal) grid pattern with a distance of about 0.30 $\mathrm{m}$ between sampling locations or to the outside edges of the bale. The sample probe was pinned to a stub shaft with a cotter pin, thereby permitting use of an electricpowered drill during sampling. Core samples from each bale $(\sim 400 \mathrm{~g})$ were placed in paper bags, and then dried to constant weight under forced air at $50^{\circ} \mathrm{C}$ to determine the pre-storage concentration of moisture for each bale. All (9) holes created during this initial sampling were filled immediately with spray-foam insulation to prevent air, sunlight, and moisture from having direct access into the bale core, and also to eliminate any easy conduits for quick dissipation of heat and moisture from the bale.

\section{Temperature Measurements}

After removal from the field, each bale was fitted with a thermocouple positioned near its geometric center, and internal bale temperatures were monitored daily at approximately $1300 \mathrm{~h}$ with an Omega 450 AKT Type K thermocouple thermometer (Omega Engineering Inc., Stamford, CT). From these data, HDD were computed for the entire storage period by summing the daily increment by which the internal bale temperature exceeded $30^{\circ} \mathrm{C}$. Therefore, HDD represented a single numeric response variable that integrated both the intensity and duration of heating for each bale across the entire storage period. Collection of temperature data was terminated 169 and $91 \mathrm{~d}$ after mowing for harvests 1 and 2, respectively, when internal bale temperatures had fallen well below the $30^{\circ} \mathrm{C}$ threshold.

\section{Post-Storage Sampling and Processing}

After accumulations of HDD had ceased, all bales again were measured for width, diameter, and final bale weight by methods similar to those described for prestorage assessments. Recoveries of DM were calculated for each bale on the basis of differences in DM weights before and after storage. On a post-storage basis, each bale was sampled via eight $0.61-\mathrm{m}$ cores using the same electric-powered drill attachment described previously. Post-storage cores were taken from the circumferential side of the bale opposite that where pre-storage samples were removed. Because bales were stored outdoors, core samples needed to reflect possible positional differences in moisture content created by exposure to the weather. Therefore, post-storage core samples were obtained from the same locations on each bale, including 2 cores each from the top (dorsal) surface, bottom (ventral) surface, and from both $30^{\circ}$ above and below the horizontal plane extending from the bale center. Post-storage samples were composited by bale $(\sim 400$ $\mathrm{g})$, and then dried to constant weight in paper bags at $50^{\circ} \mathrm{C}$ under forced air. Paper bags containing dry hay samples were weighed immediately after removal from 
the drier, and final concentrations of DM for each bale were calculated. This estimate of the final DM concentration was used subsequently to calculate the final DM weight, DM density, and DM recovery for each bale.

\section{Laboratory Analyses}

Each dried hay sample was ground through a Wiley mill (Arthur H. Thomas Co., Philadelphia, PA) equipped with a 1-mm screen. Samples were retained in sealed freezer bags pending analysis for ash, forage fiber components (NDF, ADF, hemicellulose, and lignin), CP, neutral detergent insoluble CP (NDICP), and acid detergent insoluble CP (ADICP). Ash content was determined on 1.0-g forage samples, and calculated as the percentage of total plant DM remaining after combustion in a muffle furnace at $500^{\circ} \mathrm{C}$ for $6 \mathrm{~h}$. Fiber components were determined sequentially using batch procedures outlined by Ankom Technology for an Ankom200 Fiber Analyzer (Ankom Technology, Macedon, NY). Neither sodium sulfite nor $\alpha$-amylase was included in the NDF solution. Throughout this study, concentrations of fiber components were not adjusted to remove residual ash. Concentrations of $\mathrm{CP}$, and residual $\mathrm{CP}$ remaining in neutral detergent and acid detergent residues were quantified by a rapid combustion procedure (AOAC, 1998, official method 990.03; Elementar Americas Inc., Mt. Laurel, NJ) using a conversion factor of 6.25 to convert $\mathrm{N}$ to a $\mathrm{CP}$ basis. Prior to quantifying ADICP, hay samples were digested directly in acid detergent, again using batch procedures outlined by Ankom Technology for an Ankom200 Fiber Analyzer, without preliminary sequential digestion in neutral detergent (Van Soest et al., 1991). For NDICP, sodium sulfite was omitted from preliminary digestions in neutral detergent because sodium sulfite is known to cleave disulfide bonds and dissolve cross-linked proteins, which decreases protein recovery from NDF residues (Van Soest et al., 1991). Both NDICP and ADICP were reported and discussed on a percentage of $\mathrm{CP}$ basis. Concentrations of total digestible nutrients (TDN) were estimated from appropriate inputs to the summative model (Weiss et al., 1992; NRC, 2001). The truly digestible fiber subunit of TDN was estimated from equations based on concentrations of acid detergent lignin (Weiss et al., 1992; NRC, 2001), rather than in vitro digestion of NDF in buffered rumen fluid. Previously, both in vitro true digestibility (Coblentz and Hoffman, 2009a) and TDN (Coblentz and Hoffman, 2010) have been shown to decrease in close association with HDD within heated alfalfa-orchardgrass hays, especially when TDN was calculated from lignin-derived estimates of truly digestible fiber.

\section{Statistics}

Regressions of Temperature Indices on Initial Bale Moisture. To best describe the relationships between accumulations of HDD or MAX and initial bale moisture for acid-treated and control hays, a variety of polynomial regression models were considered. These included linear, quadratic, cubic, and quartic effects of initial bale moisture, all of which were evaluated by PROC REG of SAS (SAS Institute, 1990). Generally, coefficients of determination $\left(\mathrm{R}^{2}\right)$ were used to determine the most appropriate model; however, polynomial regressions were not selected if the coefficient or slope for the highest-ordered term did not differ from $0(P$ $<0.10$ ). Alternative expressions (such as dropping the linear term from a quadratic model) were considered when tests of significance for specific coefficients suggested these actions could improve fit. All regressions were based on responses for individual bales. Because data suggested that acid treatment exhibited unique effects on heating during storage, HDD accumulated during the first $28 \mathrm{~d}$ after baling also were evaluated to best explain responses to treatment.

Regressions of DM Recovery on HDD. Past research (Coblentz and Hoffman, 2009a,b; Coblentz and Hoffman, 2010; Coblentz et al., 2010) has demonstrated that most changes that occur within large hay packages are related closely to indices quantifying the magnitude and duration of heating within the bale during storage. As such, recoveries of DM for individual bales were regressed on HDD using linear, quadratic, cubic, and quartic models (PROC REG; SAS Institute, 1990). Selection of the most appropriate model was consistent with the general framework described previously for regressions of HDD on initial bale moisture. For the regression of DM recovery on HDD, a linear regression model was most appropriate to explain responses for both acid-treated and control bales; therefore, tests of homogeneity (PROC GLM; SAS Institute, 1990) also were performed to determine whether slopes and intercepts differed on the basis of treatment, or whether they could be pooled into a single regression relationship.

Regressions of Changes in Concentrations of Nutritional Components on HDD. Although harvests 1 and 2 represented well-managed alfalfa forages that were obtained from the same field site, initial (prestorage) characteristics of nutritive value were not identical across harvests. Therefore, data were normalized for NDF, ADF, hemicellulose, acid-detergent lignin, ash, CP, NDICP, ADICP, and TDN before regression analysis by calculating the mathematical difference that occurred during storage (post-storage - pre-storage; 
$\Delta \mathrm{NDF}, \Delta \mathrm{ADF}, \Delta \mathrm{HEMI}, \Delta \mathrm{LIG}, \Delta \mathrm{ASH}, \Delta \mathrm{CP}$, $\Delta$ NDICP, $\Delta$ ADICP, and $\Delta$ TDN, respectively). These baseline-adjusted response variables were then regressed against HDD using the polynomial regression models described previously. Nonlinear regression models also were evaluated (PROC NLIN; SAS Institute, 1990) based on results of past work with large hay packages (Coblentz and Hoffman, 2009a,b; Coblentz et al., 2010; Coblentz and Hoffman, 2010). These included models of the general form $Y=b \times\left(e^{-k x}\right)-a$, if concentrations decreased with HDD (i.e., $\triangle$ TDN was negative), or $Y=a-\left(b \times e^{-k x}\right)$, if concentrations increased with HDD (i.e., $\triangle \mathrm{NDF}$ was positive). For these model assessments, $k$ was defined as the rate constant, $x$ as the independent variable (HDD), whereas $a$ and $b$ were parameters determined directly by the regression model. For each nutritional component, HDD also were squared within these nonlinear models in an attempt to improve fit. Past work (Coblentz and Hoffman, 2009b) has demonstrated that concentrations of hemicellulose respond uniquely to heating in large hay packages, increasing in response to minimal or modest heating, but then decreasing as heating becomes more severe. Because of this unique response, data for $\triangle H E M I$ were segregated on the basis of ascending and descending values, and independent regressions were fitted for each trend.

\section{RESULTS}

\section{Storage Characteristics of Hays}

Initial bale moistures for harvest 1 ranged from 17.8 to $40.4 \%$, with the overall mean for 28 control bales $(30.3 \pm 6.19 \%)$ and 25 acid-treated bales $(31.0 \pm 5.58 \%)$ being numerically similar (Table 1 ). However, harvest 2 generally included greater numbers of somewhat drier bales, resulting in decreased overall means for control and acid-treated bales $(25.5 \pm 9.07$ and $25.1 \pm 8.59 \%$, respectively), relative to harvest 1 . Generally, weights of DM within each bale, as well as DM density, varied little with treatment, or across harvests, and respective initial estimates for these physical characteristics oscillated minimally around benchmark values of $400 \mathrm{~kg}$ of $\mathrm{DM} /$ bale and $200 \mathrm{~kg}$ of $\mathrm{DM} / \mathrm{m}^{3}$.

Total accumulated HDD (Figure 1) for acid-treated bales were explained by a quadratic relationship with initial bale moisture $\left(\mathrm{Y}=2.02 \mathrm{x}^{2}-401 ; \mathrm{R}^{2}=0.77\right)$, in which the linear term was dropped from the model to improve fit. In contrast, total HDD for control bales were best explained by a nonlinear model $[\mathrm{Y}=4,112-$ $\left.\left(4,549 \times \mathrm{e}^{-0.000559^{*} \mathrm{x}^{*} \mathrm{x}}\right) ; \mathrm{R}^{2}=0.77\right]$. Generally, total accumulations of HDD were decreased by application of the acid preservative at bale moistures $<27.7 \%$; at greater initial bale moistures, fewer HDD were accumulated for control hays. Based on these regression relationships,

Table 1. Mean pre-storage and post-storage bale characteristics for large round bales of alfalfa hay made at Stratford, WI, with or without an application of a propionic acid-based preservative at baling

\begin{tabular}{|c|c|c|c|c|c|c|c|c|c|}
\hline Treatment & $\begin{array}{c}\text { Bales, } \\
\text { no. }\end{array}$ & Statistic & $\underset{\mathrm{m}^{3}}{\text { Volume }}$ & $\begin{array}{c}\text { Wet weight, } \\
\mathrm{kg}\end{array}$ & $\begin{array}{c}\text { Moisture, } \\
\%\end{array}$ & $\begin{array}{l}\text { Dry weight, } \\
\text { kg of DM }\end{array}$ & $\begin{array}{l}\text { DM density, } \\
\mathrm{kg} \text { of } \mathrm{DM} / \mathrm{m}^{3}\end{array}$ & $\begin{array}{c}\mathrm{DM} \\
\text { recovery, \% }\end{array}$ & $\underset{{ }^{\circ} \mathrm{C}}{\mathrm{MAX},{ }^{1}}$ \\
\hline \multicolumn{10}{|l|}{ Harvest 1 (2009) } \\
\hline \multicolumn{10}{|l|}{ Pre-storage } \\
\hline \multirow{2}{*}{ Control } & 28 & Mean & 1.93 & 588 & 30.3 & 407 & 211 & - & - \\
\hline & & SD & 0.101 & 63.6 & 6.19 & 22.4 & 17.5 & - & - \\
\hline \multirow[t]{2}{*}{ Acid-treated $^{2}$} & 25 & Mean & 1.90 & 604 & 31.0 & 413 & 217 & - & - \\
\hline & & SD & 0.070 & 74.6 & 5.58 & 27.8 & 15.8 & - & - \\
\hline \multicolumn{10}{|l|}{ Post-storage } \\
\hline \multirow[t]{2}{*}{ Control } & 28 & Mean & 1.80 & 424 & 18.0 & 348 & 194 & 85.6 & 66.3 \\
\hline & & SD & 0.128 & 25.8 & 2.21 & 22.2 & 17.3 & 4.28 & 11.69 \\
\hline \multirow[t]{2}{*}{ Acid-treated $^{2}$} & 25 & Mean & 1.77 & 427 & 18.8 & 347 & 196 & 84.1 & 65.8 \\
\hline \multirow{2}{*}{\multicolumn{10}{|c|}{ Harvest 2 (2010) }} \\
\hline & & & & & & & & & \\
\hline \multicolumn{10}{|l|}{ Pre-storage } \\
\hline \multirow[t]{2}{*}{ Control } & 17 & Mean & 2.05 & 535 & 25.5 & 393 & 192 & - & - \\
\hline & & $\mathrm{SD}$ & 0.049 & 66.5 & 9.07 & 19.5 & 9.8 & - & - \\
\hline \multirow[t]{2}{*}{ Acid-treated $^{2}$} & 17 & Mean & 2.03 & 542 & 25.1 & 401 & 197 & - & - \\
\hline & & $\mathrm{SD}$ & 0.059 & 73.1 & 8.59 & 21.7 & 12.6 & - & - \\
\hline \multicolumn{10}{|l|}{ Post-storage } \\
\hline \multirow[t]{2}{*}{ Control } & 17 & Mean & 2.01 & 456 & 20.0 & 364 & 181 & 92.4 & 54.2 \\
\hline & & $\mathrm{SD}$ & 0.096 & 21.7 & 6.28 & 31.3 & 16.0 & 5.97 & 9.68 \\
\hline \multirow[t]{2}{*}{ Acid-treated $^{2}$} & 17 & Mean & 1.99 & 476 & 21.8 & 371 & 186 & 92.2 & 48.7 \\
\hline & & $\mathrm{SD}$ & 0.082 & 37.5 & 6.57 & 28.1 & 15.9 & 6.04 & 7.09 \\
\hline
\end{tabular}

${ }^{1}$ Maximum internal bale temperature during storage.

${ }^{2}$ Mean calculated application rates (\% of bale weight) for bales treated with a propionic acid-based preservative across 2 yr were $0.7 \pm 0.19 \%$ (DM basis) or $0.5 \pm 0.14 \%$ (as-is basis). 
the maximum decrease of HDD as a result of acid treatment was about $67 \mathrm{HDD}$, and this occurred when the initial bale moisture was about $20 \%$. Acid-treated bales commonly maintained elevated bale temperatures longer than control bales, thereby masking much stronger effects of acid treatment during the first $28 \mathrm{~d}$ of storage (Figure 2). At $28 \mathrm{~d}$, the most appropriate regression models for acid-treated and control hays were identical to those for the full storage period; however, coefficients of determination improved for both acid-treated $(\mathrm{Y}=$ $\left.0.72 \mathrm{x}^{2}-122 ; \mathrm{R}^{2}=0.84\right)$ and control $[\mathrm{Y}=1,399-(1,568$ $\left.\left.\times \mathrm{e}^{-0.000816^{*} \mathrm{x}^{*} \mathrm{x}}\right) ; \mathrm{R}^{2}=0.86\right]$ hays. More importantly, benefits of acid-treatment were observed when initial bale moistures were $<38.1 \%$, with a maximum differential of about 134 HDD that occurred at approximately $26.6 \%$ moisture.

During storage, the mean MAX for control and acidtreated bales from harvest 1 varied minimally (66.3 vs. $65.8^{\circ} \mathrm{C}$, respectively; Table 1 ); however, a much larger differential was observed for harvest $2\left(54.2\right.$ vs. $48.7^{\circ} \mathrm{C}$, respectively), which suggests a measureable suppression of internal bale temperature as a result of acid treatment. Regressions of MAX on initial bale moisture (data not shown) were complicated by the inclusion of 7 bales that received $51 \mathrm{~mm}$ of rainfall before baling; rain damage had a perturbing effect on normal heating patterns in these bales, resulting in a disproportionately elevated MAX, but comparable total accumulations of HDD relative to other hays baled without rain damage at similar moisture concentrations. After eliminating these bales from regression analysis, MAX was best fitted to a quadratic model $\left(\mathrm{Y}=0.057 \mathrm{x}^{2}-1.47 \mathrm{x}+48.8\right.$; $\mathrm{R}^{2}=0.76 ; \mathrm{n}=38$ bales) for acid-treated hays, but the linear term was dropped for control hays to improve fit $\left(\mathrm{Y}=0.027 \mathrm{x}^{2}+37.2 ; \mathrm{R}^{2}=0.78 ; \mathrm{n}=42\right.$ bales $)$. Based on these regressions, acid-treatment decreased MAX relative to control hays at all initial concentrations of bale moisture $<39.6 \%$, and the maximum benefit derived from acid-treatment was a differential of $6.6^{\circ} \mathrm{C}$, which occurred when the initial bale moisture was $24.8 \%$.

Overall, recoveries of DM following storage ranged from 76.2 to $100.0 \%$, with the extensive DM losses in some bales generally being associated with the greatest concentrations of initial bale moisture. When recoveries of DM were regressed on HDD, linear models were obtained for both acid-treated and control bales (Figure 3). Subsequent tests for homogeneity of slopes and intercepts indicated that neither slopes $(P=0.98)$ nor intercepts $(P=0.23)$ differed on the basis of treatment, and a pooled regression $\left(\mathrm{Y}=-0.0066 \mathrm{x}+96.3 ; \mathrm{R}^{2}=\right.$ $0.75)$ best described the relatively close negative association between recoveries of DM and HDD incurred during storage. The homogeneity of slopes suggests that any benefits of acid treatment for preservation of DM

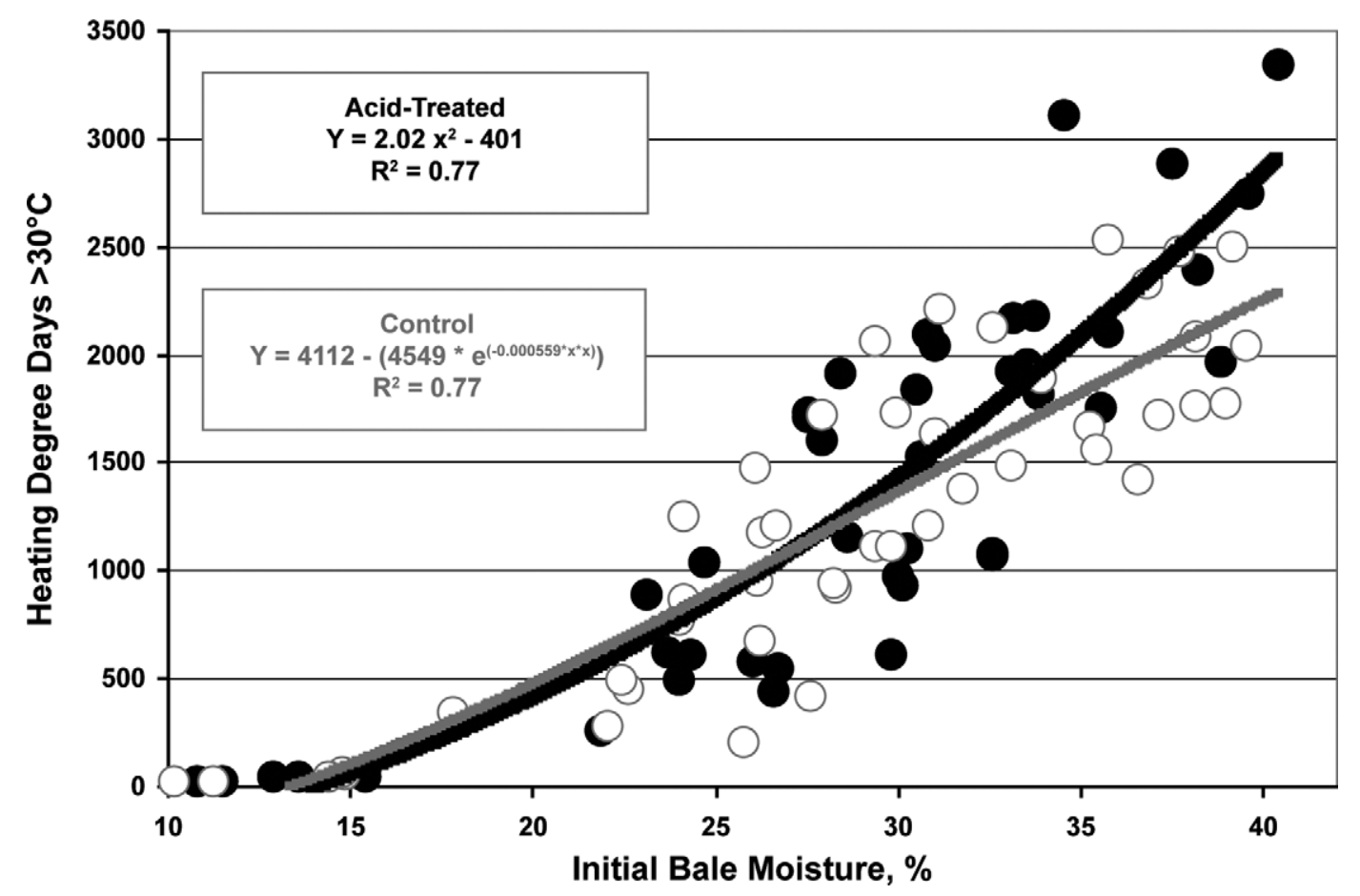

Figure 1. Relationships between heating degree days $>30^{\circ} \mathrm{C}$ accumulated during storage and initial bale moisture for large round bales of alfalfa hay made with $(\bullet$, black line) or without $(\bigcirc$, grey line) application of a propionic acid-based preservative. Data are pooled over 2 harvests, and each data point represents an individual bale. 


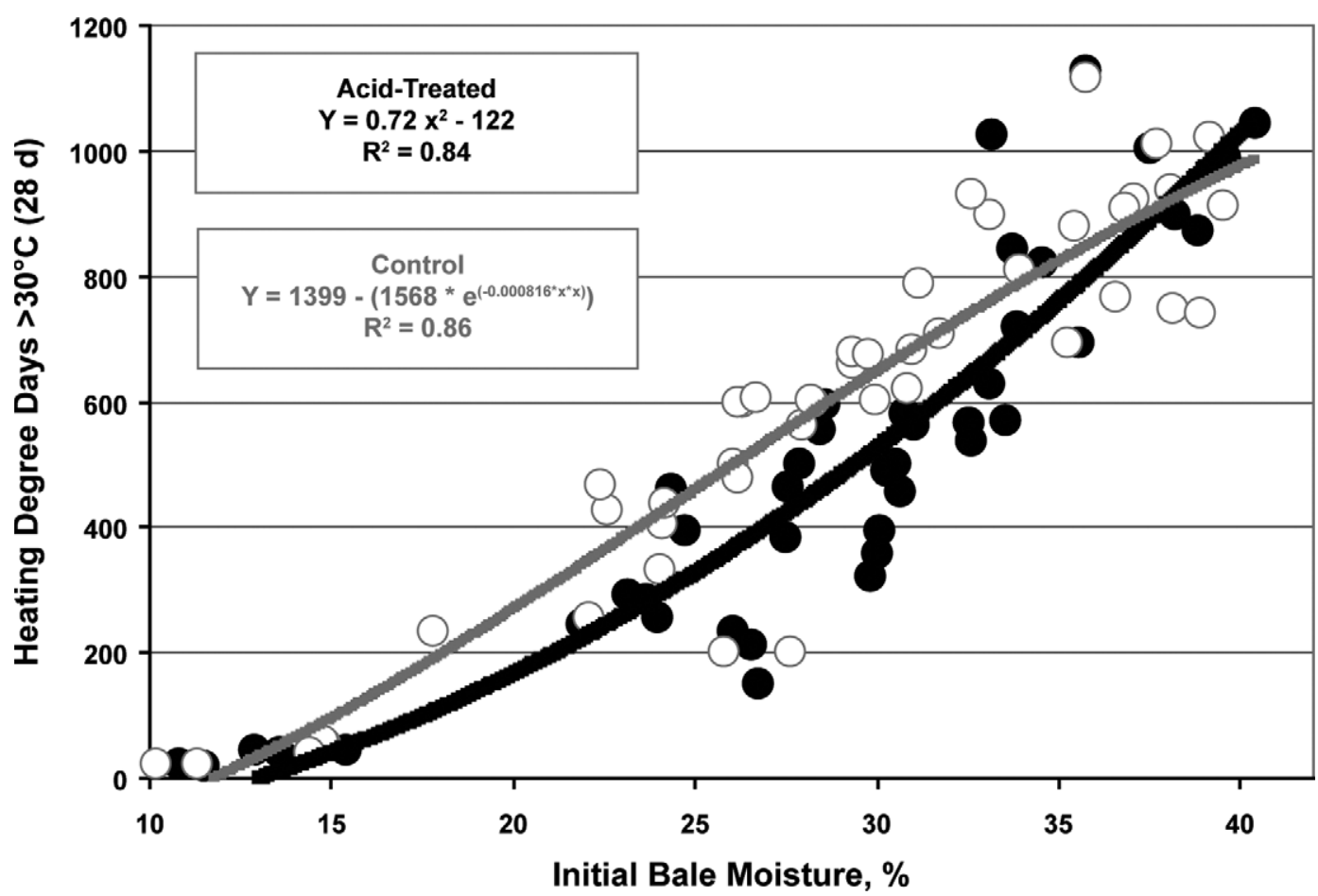

Figure 2. Relationships between heating degree days $>30^{\circ} \mathrm{C}$ accumulated during the first $28 \mathrm{~d}$ of storage and initial bale moisture for large

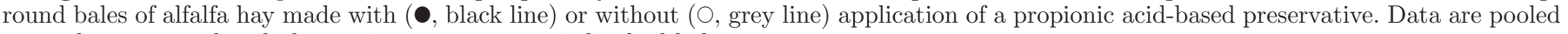
over 2 harvests, and each data point represents an individual bale.

occur primarily through abatement of heating, rather than by other mechanisms.

\section{Forage Nutritive Value}

Concentrations of NDF, ADF, hemicellulose, lignin, and ash from evaluations of harvests 1 and 2 are summarized on a pre-storage and post-storage basis in Table 2. Similarly, respective summaries of pre-storage and post-storage concentrations of CP, NDICP, ADICP, and TDN are summarized in Table 3.

Fiber Components. Generally, harvests 1 and 2 represented hays of relatively high nutritive value in which respective mean concentrations of NDF for control and acid-treated hays were slightly lower for harvest $1(37.0 \pm 1.30$ and $36.8 \pm 1.86 \%)$ than for harvest $2(40.5 \pm 1.56$ and $40.1 \pm 1.53 \%)$. Changes in concentrations of NDF during storage (post-storage pre-storage; $\triangle \mathrm{NDF}$ ) increased rapidly (Table 4 ), and in close association with HDD for both acid-treated and control hays. The nonlinear regression relationship for the control hays $\left[\mathrm{Y}=11.5-\left(12.5 \times \mathrm{e}^{-0.000028^{*} \mathrm{x}^{*} \mathrm{x}}\right) ; \mathrm{R}^{2}\right.$ $=0.85]$ suggested a more rapid increase in NDF with modest heating than observed for acid-treated hays $(\mathrm{Y}$ $=0.0000000022 \mathrm{x}^{3}-0.000013 \mathrm{x}^{2}+0.024 \mathrm{x}-0.6 ; \mathrm{R}^{2}=$ $0.83)$, which may be related to the greater maximum temperatures observed generally for control hays. The cubic nature of the regression for acid-treated hays depicts a decreasing trend for $\triangle \mathrm{NDF}$ with severe heating that may be related to increased reactivity of hemicellulose in these hays (Van Soest, 1982). The asymptotic nature of the best-fitted response curve for control hays likely masked similar hemicellulose reactivity; control bales incurring $>2,000$ HDD generally exhibited estimates of $\Delta \mathrm{NDF}$ that were less than the 11.5 percentage-unit asymptotic limit established by the nonlinear regression curve.

Unlike $\triangle \mathrm{NDF}$, the selected regression models describing $\triangle \mathrm{ADF}$ for acid-treated and control hays were both nonlinear (Table 4), and residuals were not minimized by squaring HDD. Both acid-treated $[\mathrm{Y}=13.7-(13.0$ $\left.\left.\times \mathrm{e}^{-0.00066^{*} \mathrm{x}}\right) ; \mathrm{R}^{2}=0.79\right]$ and control $[\mathrm{Y}=16.3-(16.4$ $\left.\left.\times \mathrm{e}^{-0.00051^{*} \mathrm{x}}\right) ; \mathrm{R}^{2}=0.75\right]$ hays exhibited similar close associations with HDD. Unlike $\triangle \mathrm{NDF}$, greater changes in $\mathrm{ADF}$ were observed for control hays over the entire heating continuum. Based on regression curves, $\triangle \mathrm{ADF}$ for control hays was greater than observed for acidtreated hays by amounts ranging between 0.5 to 2.0 percentage units for any hay incurring more than about 1,000 HDD.

As observed previously for heated hays packaged in large round bales (Coblentz and Hoffman, 2009b), re- 
Table 2. Mean pre-storage and post-storage concentrations (\% of DM) of fiber components and ash for large round bales of alfalfa hay made at Stratford, WI, with or without an application of a propionic acid-based preservative at baling

\begin{tabular}{|c|c|c|c|c|c|c|c|}
\hline Treatment & $\begin{array}{c}\text { Bales, } \\
\text { no. }\end{array}$ & Statistic & $\mathrm{NDF}$ & $\mathrm{ADF}$ & Hemicellulose & Lignin & Ash \\
\hline \multicolumn{8}{|l|}{ Harvest 1 (2009) } \\
\hline \multicolumn{8}{|l|}{ Pre-storage } \\
\hline \multirow[t]{2}{*}{ Control } & 25 & Mean & 37.0 & 26.6 & 10.4 & 4.3 & 11.7 \\
\hline & & SD & 1.30 & 1.06 & 0.36 & 0.34 & 0.66 \\
\hline \multirow{2}{*}{ Acid-treated $^{1}$} & 21 & Mean & 36.8 & 26.4 & 10.4 & 4.2 & 11.6 \\
\hline & & SD & 1.86 & 1.46 & 0.53 & 0.35 & 0.60 \\
\hline \multicolumn{8}{|l|}{ Post-storage } \\
\hline \multirow{2}{*}{ Control } & 25 & Mean & 47.8 & 35.8 & 12.0 & 10.2 & 12.7 \\
\hline & & $\mathrm{SD}$ & 1.38 & 2.82 & 2.84 & 2.49 & 1.20 \\
\hline \multirow[t]{2}{*}{ Acid-treated $^{1}$} & 21 & Mean & 47.7 & 35.9 & 11.7 & 10.1 & 12.8 \\
\hline & & SD & 1.13 & 2.07 & 2.54 & 1.97 & 1.02 \\
\hline \multicolumn{8}{|l|}{ Harvest 2 (2010) } \\
\hline \multicolumn{8}{|l|}{ Pre-storage } \\
\hline \multirow[t]{2}{*}{ Control } & 17 & Mean & 40.5 & 29.9 & 10.5 & 4.5 & 11.6 \\
\hline & & $\mathrm{SD}$ & 1.56 & 1.52 & 0.76 & 0.49 & 0.48 \\
\hline \multirow{2}{*}{ Acid-treated $^{1}$} & 17 & Mean & 40.1 & 29.4 & 10.7 & 4.4 & 11.6 \\
\hline & & SD & 1.53 & 1.74 & 0.67 & 0.44 & 0.67 \\
\hline \multicolumn{8}{|l|}{ Post-storage } \\
\hline \multirow[t]{2}{*}{ Control } & 17 & Mean & 49.3 & 34.2 & 15.2 & 6.8 & 12.4 \\
\hline & & SD & 6.22 & 4.17 & 2.55 & 1.70 & 0.97 \\
\hline \multirow[t]{2}{*}{ Acid-treated $^{1}$} & 17 & Mean & 48.2 & 32.9 & 15.3 & 6.2 & 12.3 \\
\hline & & SD & 6.17 & 4.06 & 2.77 & 1.63 & 0.98 \\
\hline
\end{tabular}

${ }^{1}$ Mean calculated application rates (\% of bale weight) for bales treated with a propionic acid-based preservative across 2 yr were $0.7 \pm 0.19 \%$ (DM basis) or $0.5 \pm 0.14 \%$ (as-is basis).

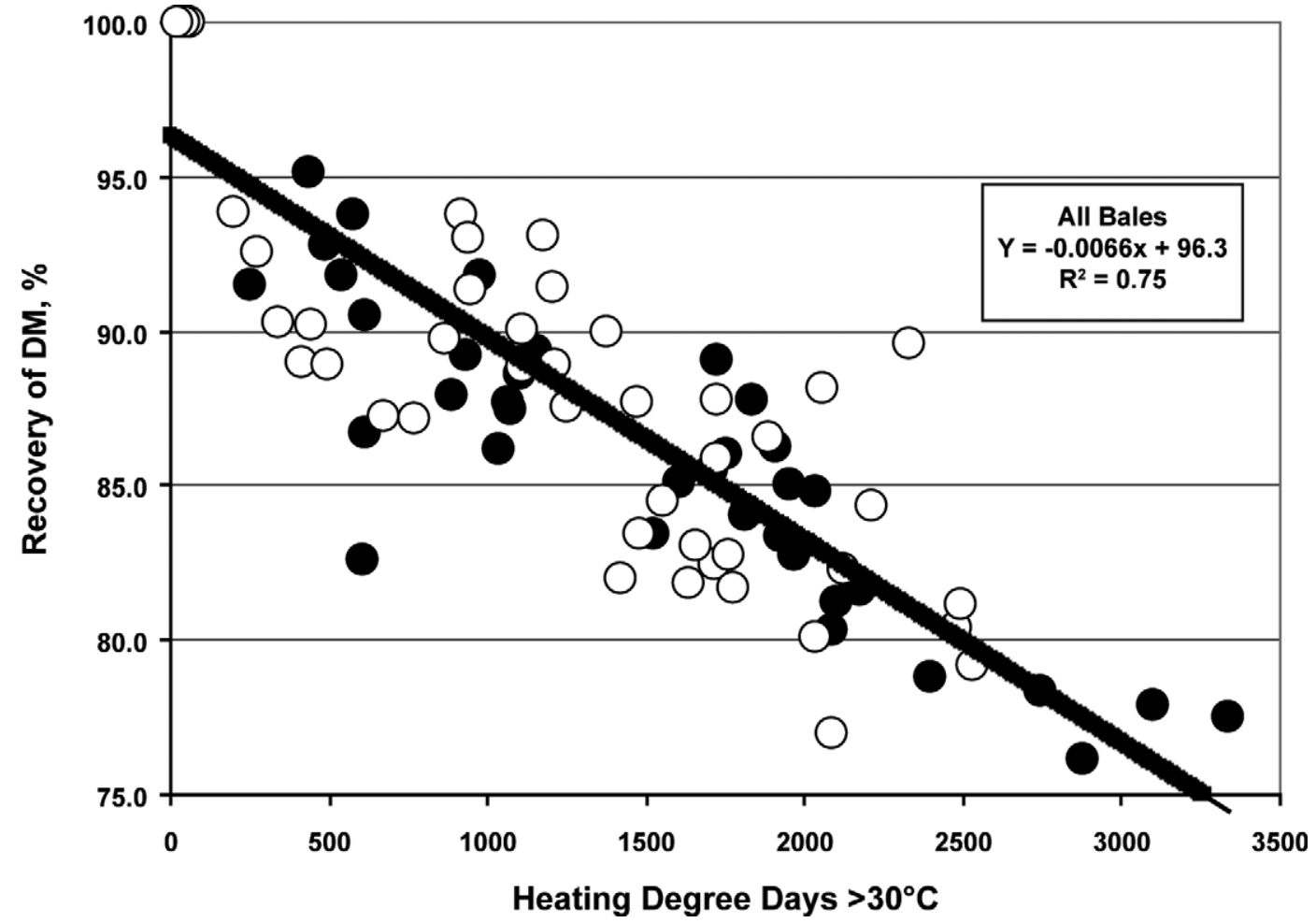

Figure 3. Relationships between recovery of DM and heating degree days $>30^{\circ} \mathrm{C}$ accumulated during storage for large round bales of alfalfa hay made with $(\bullet)$ or without $(O)$ application of a propionic acid-based preservative. Slopes $(P=0.98)$ and intercepts $(P=0.23)$ did not differ for acid-treated or control hays; therefore, all data are merged (black line) into a single regression. Data also are pooled over 2 harvests, and each data point represents an individual bale. 
Table 3. Mean pre-storage and post-storage concentrations of $\mathrm{CP}$, neutral detergent insoluble CP (NDICP), acid detergent insoluble CP (ADICP), and total digestible nutrients (TDN) for large round bales of alfalfa hay made at Stratford, Wisconsin, with or without an application of a propionic acid-based preservative at baling

\begin{tabular}{|c|c|c|c|c|c|c|c|c|}
\hline Treatment & $\begin{array}{c}\text { Bales, } \\
\text { no. }\end{array}$ & Statistic & $\begin{array}{c}\text { CP, } \\
\% \text { of DM }\end{array}$ & $\begin{array}{l}\text { NDICP, } \\
\% \text { of DM }\end{array}$ & $\begin{array}{l}\text { ADICP, } \\
\% \text { of DM }\end{array}$ & $\begin{array}{l}\text { NDICP, } \\
\% \text { of CP }\end{array}$ & $\begin{array}{l}\text { ADICP, } \\
\% \text { of CP }\end{array}$ & $\begin{array}{l}\text { TDN, } \\
\% \text { of DM }\end{array}$ \\
\hline \multicolumn{9}{|l|}{ Harvest 1 (2009) } \\
\hline \multicolumn{9}{|l|}{ Pre-storage } \\
\hline \multirow[t]{2}{*}{ Control } & 25 & Mean & 22.6 & 2.79 & 1.41 & 12.4 & 6.3 & 61.8 \\
\hline & & SD & 0.59 & 0.284 & 0.324 & 1.16 & 1.38 & 1.04 \\
\hline \multirow[t]{2}{*}{ Acid-treated $^{1}$} & 21 & Mean & 22.6 & 2.74 & 1.40 & 12.1 & 6.2 & 62.2 \\
\hline & & SD & 0.77 & 0.280 & 0.374 & 1.21 & 1.54 & 1.09 \\
\hline \multicolumn{9}{|l|}{ Post-storage } \\
\hline \multirow[t]{2}{*}{ Control } & 25 & Mean & 23.8 & 10.18 & 5.46 & 42.9 & 22.7 & 47.9 \\
\hline & & SD & 0.86 & 0.506 & 2.730 & 2.42 & 10.91 & 5.92 \\
\hline \multirow{2}{*}{ Acid-treated ${ }^{1}$} & 21 & Mean & 24.3 & 10.11 & 5.36 & 41.6 & 21.8 & 47.9 \\
\hline & & SD & 0.84 & 0.285 & 2.361 & 2.31 & 9.18 & 4.65 \\
\hline \multicolumn{9}{|l|}{ Harvest 2 (2010) } \\
\hline \multicolumn{9}{|l|}{ Pre-storage } \\
\hline \multirow[t]{2}{*}{ Control } & 17 & Mean & 22.9 & 4.37 & 1.78 & 19.1 & 7.8 & 60.6 \\
\hline & & SD & 0.57 & 0.351 & 0.294 & 1.55 & 1.43 & 1.30 \\
\hline \multirow[t]{2}{*}{ Acid-treated ${ }^{1}$} & 17 & Mean & 22.9 & 4.31 & 1.74 & 18.8 & 7.6 & 60.9 \\
\hline & & SD & 0.54 & 0.331 & 0.363 & 1.27 & 1.50 & 1.26 \\
\hline \multicolumn{9}{|l|}{ Post-storage } \\
\hline \multirow{2}{*}{ Control } & 17 & Mean & 24.3 & 9.73 & 3.20 & 39.8 & 13.1 & 53.5 \\
\hline & & SD & 0.84 & 3.236 & 1.319 & 12.41 & 5.24 & 5.74 \\
\hline \multirow[t]{2}{*}{ Acid-treated $^{1}$} & 17 & Mean & 24.1 & 8.99 & 2.69 & 36.9 & 11.0 & 55.0 \\
\hline & & SD & 0.82 & 3.064 & 1.032 & 11.92 & 3.97 & 5.34 \\
\hline
\end{tabular}

${ }^{1}$ Mean calculated application rates ( $\%$ of bale weight) for bales treated with a propionic acid-based preservative across 2 yr were $0.7 \pm 0.19 \%$ (DM basis) or $0.5 \pm 0.14 \%$ (as-is basis).

gression relationships for $\triangle \mathrm{HEMI}$ were distinctly different than those observed for other fiber components (Table 4). For both acid-treated and control hays, $\triangle$ HEMI increased with minimal or modest heating, but then decreased in severely heated hays. With low-to-modest heating, acid-treated $\left[\mathrm{Y}=6.7-\left(7.0 \times \mathrm{e}^{-0.0031^{*} \mathrm{x}}\right) ; \mathrm{R}^{2}=\right.$ $0.85]$ and control $\left(\mathrm{Y}=0.000000015 \mathrm{x}^{3}-0.000028 \mathrm{x}^{2}+\right.$ $\left.0.020 \mathrm{x}-0.2 ; \mathrm{R}^{2}=0.97\right)$ hays exhibited close relationships with HDD that were maximized at 6.5 and 8.3 percentage units, respectively. These intersection points between ascending and descending responses occurred at approximately 1,100 HDD, regardless of treatment. Descending portions of the responses for $\triangle$ HEMI were best fitted to nonlinear models with the independent variable squared for both acid-treated and control hays, but coefficients of determination were substantially poorer $\left(\mathrm{R}^{2} \leq 0.66\right)$ than observed with only minimalto-modest heating. After reaching maximum values for $\triangle$ HEMI at about 1,100 HDD, $\triangle$ HEMI decreased more rapidly for control hays, obtaining a maximum differential from acid-treated hays of 1.9 percentage units at 1,685 HDD.

Concentrations of acid-detergent lignin for all hays increased with HDD during storage (Table 4); however, the most appropriate regression model contrasted sharply between acid-treated and control hays. Control hays were fitted to a simple linear model that explained approximately $2 / 3$ of the variability in the data set (Y $\left.=0.0030 \mathrm{x}+0.5 ; \mathrm{R}^{2}=0.65\right)$. In contrast, the best model for acid-treated bales was a quartic polynomial with an improved coefficient of determination $\left(\mathrm{R}^{2}=0.82\right)$. It remains unclear why the regression curve for acid-treated hays fit a decreasing $\Delta$ LIG for the most severely heated hays; in practical terms, this may reflect overfitting of $\Delta$ LIG, masking what may have been a static response when HDD $>2,500$. Generally, acid treatment resulted in decreased $\triangle$ LIG throughout the heating continuum whenever HDD $<2,500$, and this differential was maximized at about 1.3 percentage units at 1,537 HDD. More importantly, increases in $\triangle$ LIG within severely heated hays represented an approximate tripling of the initial concentrations of acid-detergent lignin, regardless of treatment, which was the greatest proportional response observed for any fiber component.

$\boldsymbol{A s h}$. Concentrations of ash increased in response to heating (Table 4); $\Delta \mathrm{ASH}$ for control hays was best fitted to a simple linear regression model that explained more than half of the variability in the data $\left(\mathrm{Y}=0.00078 \mathrm{x}-0.1 ; \mathrm{R}^{2}=0.54\right)$. The coefficient of determination for acid-treated hays was improved $\left(\mathrm{R}^{2}\right.$ $=0.61$ ) with a quartic model, but the overall trends for $\Delta \mathrm{ASH}$ were generally similar across treatments with maximum increases, as defined by the regression curves, equaling approximately 2 percentage units of DM within severely heated hays.

CP Components. Regression analysis for $\Delta \mathrm{CP}$ (Table 4) yielded similar responses to those described for $\Delta \mathrm{ASH}$. For both acid-treated and control hays, 
Table 4. Regressions of the changes in concentrations of NDF, ADF, hemicellulose, acid detergent lignin, ash, CP, neutral detergent insoluble CP, acid detergent insoluble CP, and total digestible nutrients (post-storage - pre-storage; $\triangle \mathrm{NDF}, \Delta \mathrm{ADF}, \Delta \mathrm{HEMI}, \Delta \mathrm{LIG}, \Delta \mathrm{ASH}, \Delta \mathrm{CP}, \Delta \mathrm{NDICP}, \Delta \mathrm{ADICP}$, and $\Delta \mathrm{TDN}$, respectively) on heating degree days $>30^{\circ} \mathrm{C}$ for acid-treated or control alfalfa hays packaged within large round bales ${ }^{1}$

\begin{tabular}{|c|c|c|c|c|c|}
\hline $\begin{array}{l}\text { Dependent } \\
\text { variable }\end{array}$ & Treatment & $\begin{array}{l}\text { Pre-storage } \\
\text { mean }^{2}\end{array}$ & $\begin{array}{l}\text { Model } \\
\text { type }\end{array}$ & Model & $\mathrm{R}^{2}$ \\
\hline \multirow[t]{2}{*}{$\Delta \mathrm{NDF}, \%$ of $\mathrm{DM}$} & Acid & 38.4 & Cubic & $Y=0.0000000022 x^{3}-0.000013 x^{2}+0.024 x-0.6$ & 0.83 \\
\hline & Control & - & ${\text { Nonlinear } 2^{3}}$ & $\mathrm{Y}=11.5-\left(12.5 \times \mathrm{e}^{\left(-0.000028 \mathrm{x}^{*} \mathrm{x}\right)}\right)$ & 0.85 \\
\hline \multirow[t]{2}{*}{$\Delta \mathrm{ADF}, \%$ of $\mathrm{DM}$} & Acid & 27.8 & Nonlinear & $\mathrm{Y}=13.7-\left(13.0 \times \mathrm{e}^{\left(-0.00066^{*} \mathrm{x}\right)}\right)$ & 0.79 \\
\hline & Control & - & Nonlinear & $\mathrm{Y}=16.3-\left(16.4 \times \mathrm{e}^{\left(-0.00051^{*} \mathrm{x}\right)}\right)$ & 0.75 \\
\hline \multirow{4}{*}{$\triangle$ HEMI, $\%$ of DM } & Acid $^{4}$ & 10.5 & Nonlinear & $\mathrm{Y}=6.7-\left(7.0 \times \mathrm{e}^{\left(-0.0031^{*} \mathrm{x}\right)}\right)$ & 0.85 \\
\hline & Acid $^{5}$ & - & Nonlinear2 & $\left.\mathrm{Y}=12.5 \times \mathrm{e}^{\left(-0.00000024^{*} \mathrm{x}^{*} \mathrm{x}\right)}\right)^{\prime}-2.9$ & 0.66 \\
\hline & Control $^{4}$ & - & Cubic & $Y=0.000000015 x^{3}-0.000028 x^{2}+0.020 x-0.2$ & 0.97 \\
\hline & Control $^{5}$ & - & Nonlinear2 & $\left.\mathrm{Y}=30.0 \times \mathrm{e}^{\left(-0.0000011^{*} \mathrm{x}^{*} \mathrm{x}\right)}\right)$ & 0.50 \\
\hline \multirow{2}{*}{$\Delta \mathrm{LIG}, \%$ of $\mathrm{DM}$} & Acid & 4.3 & Quartic & $Y=-0.00000000000096 x^{4}+0.0000000058 x^{3}-0.000011 x^{2}+0.0091 x-0.2$ & 0.82 \\
\hline & Control & - & Linear & $\mathrm{Y}=0.0030 \mathrm{x}+0.5$ & 0.65 \\
\hline \multirow[t]{2}{*}{$\Delta \mathrm{ASH}, \%$ of $\mathrm{DM}$} & Acid & 11.6 & Quartic & $Y=-0.00000000000025 x^{4}+0.0000000017 x^{3}-0.0000038 x^{2}+0.0031 x-0.1$ & 0.61 \\
\hline & Control & - & Linear & $Y=0.00078 x-0.1$ & 0.54 \\
\hline \multirow[t]{2}{*}{$\Delta \mathrm{CP}, \%$ of $\mathrm{DM}$} & Acid & 22.7 & Cubic & $\mathrm{Y}=0.00000000027 \mathrm{x}^{3}-0.0000012 \mathrm{x}^{2}+0.0021 \mathrm{x}+0.2$ & 0.55 \\
\hline & Control & - & Linear & $\mathrm{Y}=0.00058 \mathrm{x}+0.5$ & 0.20 \\
\hline \multirow[t]{2}{*}{$\triangle \mathrm{NDICP}, \%$ of $\mathrm{CP}$} & Acid & 15.1 & Nonlinear2 & $\mathrm{Y}=28.7-\left(29.0 \times \mathrm{e}^{\left(-0.0000068^{*} \mathrm{x}^{*} \mathrm{x}\right)}\right)$ & 0.92 \\
\hline & Control & - & Nonlinear2 & $\mathrm{Y}=29.8-\left(30.6 \times \mathrm{e}^{\left(-0.000051^{*} \mathrm{x}^{*} \mathrm{x}\right)}\right)^{\prime}$ & 0.91 \\
\hline \multirow[t]{2}{*}{$\triangle \mathrm{ADICP}, \%$ of $\mathrm{CP}$} & Acid & 6.9 & Nonlinear2 & $\mathrm{Y}=30.7-\left(31.2 \times \mathrm{e}^{\left(-0.00000018^{*} \mathrm{x}^{* \mathrm{x})}\right)}\right)$ & 0.74 \\
\hline & Control & - & Nonlinear2 & $\left.\mathrm{Y}=32.6-\left(33.1 \times \mathrm{e}^{\left(-0.00000026^{*} \mathrm{x}^{*} \mathrm{x}\right)}\right)^{\prime}\right)$ & 0.65 \\
\hline \multirow[t]{2}{*}{$\Delta \mathrm{TDN}, \%$ of $\mathrm{DM}$} & Acid & 61.5 & Quartic & $\mathrm{Y}=0.0000000000017 \mathrm{x}^{4}-0.000000011 \mathrm{x}^{3}+0.000023 \mathrm{x}^{2}-0.023 \mathrm{x}+0.8$ & 0.88 \\
\hline & Control & - & Nonlinear & $\left.\mathrm{Y}=39.1 \times \mathrm{e}^{(-0.00027 \mathrm{x})}\right)-39.3$ & 0.79 \\
\hline
\end{tabular}

${ }^{1}$ Data are pooled over 2 harvests, and each data point represents an individual bale. There were 38 acid-treated and 42 control bales included in the regression analysis for each dependent variable.

${ }^{2}$ Mean concentration of each nutritional component weighted on the basis of the number of total bales from 2009 and 2010 harvests; generally, this value corresponds to $\Delta=0$ on the y-axis.

${ }^{3}$ Nonlinear2 denotes a nonlinear model in which the independent variable (heating degree days $>30^{\circ} \mathrm{C}$ ) was squared to improve fit.

ㄱ. ${ }^{4}$ Regression limited to bales incurring low-to-modest heating, where $\triangle$ HEMI was increasing.

‥ $\quad{ }^{5}$ Regression limited to bales incurring modest-to-severe heating, where $\Delta$ HEMI was decreasing. 
$\triangle \mathrm{CP}$ increased with heating; however, the best-fitted model was linear for control hays $(\mathrm{Y}=0.00058 \mathrm{x}+$ $\left.0.5 ; \mathrm{R}^{2}=0.20\right)$, but cubic for those treated with the acid preservative $\left(\mathrm{Y}=0.00000000027 \mathrm{x}^{3}-0.0000012 \mathrm{x}^{2}\right.$ $\left.+0.0021 \mathrm{x}+0.2 ; \mathrm{R}^{2}=0.55\right)$. Control hays exhibited an erratic, widely scattered response, resulting in a poor coefficient of determination. Although the cubic model selected for acid-treated hays explained more than half the variability within the data, in practical terms it represented an overall response differing only minimally from that exhibited by control hays. For acid-treated hays, $\triangle \mathrm{CP}$ exceeded 3 percentage units when HDD $>3,000$, which represented an approximate $13 \%$ increase during storage.

For both acid-treated and control hays, $\triangle$ NDICP $(\%$ of CP) increased sharply with only minimal heating (Table 4) before responses became asymptotic; these data were best fitted to nonlinear regression models in which the independent variable was squared. Coefficients of determination indicated very close regression relationships between $\triangle$ NDICP and HDD for both acid-treated $\left[\mathrm{Y}=28.7-\left(29.0 \times \mathrm{e}^{-0.0000068 \mathrm{x}^{*} \mathrm{x}}\right) ; \mathrm{R}^{2}=\right.$ $0.92]$ and control $\left[\mathrm{Y}=29.8-\left(30.6 \times \mathrm{e}^{-0.000051 \mathrm{x}^{*} \mathrm{x}}\right) ; \mathrm{R}^{2}\right.$ $=0.91]$ hays. The 7.5 -fold greater estimate of rate $(k)$ for control hays suggests that acid treatment exhibited a measureable effect on slowing formation of NDICP in modestly heated hays, but little practical difference existed between baling treatments when HDD $>1,000$. Regardless of treatment, $\triangle$ NDICP reached maxima of almost 30 percentage units of $\mathrm{CP}$, which approximately tripled the concentrations within pre-storage hays.

Concentrations of ADICP (\% of CP) also increased sharply in response to heating; $\triangle \mathrm{ADICP}$ exceeded 25 percentage units of $\mathrm{CP}$ in severely heated bales, regardless of treatment, which means that final concentrations of ADICP in these hays were about 5 times those measured before storage. Regressions of $\triangle \mathrm{ADICP}$ on HDD (Table 4) were best fitted to nonlinear models in which the independent variable was squared for both acid-treated $\left[\mathrm{Y}=30.7-\left(31.2 \times \mathrm{e}^{-0.00000018 \mathrm{x}^{*} \mathrm{x}}\right) ; \mathrm{R}^{2}=\right.$ $0.74]$ and control $\left[\mathrm{Y}=32.6-\left(33.1 \times \mathrm{e}^{-0.00000026 \mathrm{x}^{*} \mathrm{x}}\right)\right.$; $\left.\mathrm{R}^{2}=0.65\right]$ hays. However, in neither case did these regression relationships become asymptotic within the range of heating observed in these experiments. Acidtreatment exhibited a mitigating effect on concentrations of ADICP; the regression curve for acid-treated bales yielded decreased values for $\triangle \mathrm{ADICP}$ throughout our entire range of HDD. In addition, the differential between acid-treated and control bales tended to increase as heating became more severe, reaching about 5.5 percentage units of $\mathrm{CP}$ at 2,500 HDD.

$T \boldsymbol{D N}$. Estimates of TDN decreased by more than 20 percentage units in severely heated hays. Generally, declining estimates of TDN were associated closely with heating, although best regression models for acidtreated $\left[\mathrm{Y}=0.0000000000017 \mathrm{x}^{4}-0.000000011 \mathrm{x}^{3}+\right.$ $\left.0.000023 \mathrm{x}^{2}-0.023 \mathrm{x}+0.8 ; \mathrm{R}^{2}=0.88\right]$ and control $[\mathrm{Y}=$ $\left.\left(39.1 \times \mathrm{e}^{-0.00027^{*} \mathrm{x}}\right)-39.3 ; \mathrm{R}^{2}=0.79\right]$ hays differed (Table 4). Regardless of treatment, $\triangle \mathrm{TDN}$ for severely heated hays suggests losses of about $33 \%$ of the pre-storage energy value of the hay. Some limiting of $\triangle T D N$ occurred as a result of acid treatment; the differential between regression curves was as much as 2.8 percentage units (more positive for acid-treated hays) at about 1,700 HDD, and advantages for acid treatment were observed consistently whenever HDD >825.

\section{DISCUSSION}

\section{Storage Characteristics}

Temperature development in hay bales, measured as HDD, clearly was decreased by acid treatment; however, several unique trends observed within acid-treated bales complicate the interpretation of results. Previously, applications of propionic acid-based preservatives decreased internal bale temperatures or HDD accumulated within small square bale packages during storage (Sheaffer and Clark, 1975; Jafri et al., 1979; Rotz et al., 1991), but Shinners (2000) observed only mixed results with large square bale packages. Generally, Rotz et al. (1991) observed only numerically decreased HDD when bales were packaged in close proximity to the threshold moisture concentration for satisfactory storage of small square bales (20\%; Collins et al., 1987), but statistically significant improvements were observed in wetter hays. Rotz et al. (1991) also suggested that the hygroscopic nature of propionic acid caused acid-treated hays to retain moisture, and exhibit greater concentrations of bale moisture than control hays for months after baling. Our results were largely consistent with those of Rotz et al. (1991). Although not compared statistically, acid-treated bales were slightly wetter on the final sampling date (Table 1), and exhibited a decreased MAX across most of the range of initial concentrations of bale moisture. However, the most unique observation was that acid-treated bales tended to heat longer than control bales. This observation is not simple to quantify; however, after $75 \mathrm{~d}$ of storage during harvest 1 , only 21 of 28 control bales were still accumulating HDD. Of these, only 6 were accumulating more than $10 \mathrm{HDD} / \mathrm{d}$. In contrast, all 25 acid-treated bales were still accumulating HDD after $75 \mathrm{~d}$ in storage, and 17 of these at a rate $>10 \mathrm{HDD} / \mathrm{d}$. For harvest 2, only 4 of 17 control hays were actively accumulating HDD after $60 \mathrm{~d}$ in storage compared with almost 3 times that number (11 of 17) for acid-treated bales. As a result of these characteristics, acid-treated hays baled at initial 
moistures $>27.7 \%$ accumulated more total HDD than control bales (Figure 1), and mitigation of heating by acid treatment was much more evident during the first $28 \mathrm{~d}$ of storage (Figure 2) than summations of HDD made over the entire storage period (Figure 1).

The perturbation of normal heating patterns as a consequence of acid treatment had no effect on recoveries of DM following storage. In previous work (Coblentz and Hoffman, 2009a), DM recoveries of alfalfa-orchardgrass (Dactylis glomerata L.) hays packaged in large round bales without acid preservatives were associated with both HDD and MAX in negative linear regression relationships with relatively high coefficients of determination. These observations were corroborated in the present study; furthermore, linear regressions for acid-treated and control bales did not differ (Figure 3), thereby indicating that DM losses were likely direct functions of the actual heat production within each bale, and that acid treatment only affected recovery of DM indirectly through its mitigating effects on microbial activity and subsequent heat production.

\section{Forage Nutritive Value}

In previous experiments with small square bales, changes in various indices of nutritive value have been related to HDD, mostly with simple linear models (Coblentz et al., 1996; Coblentz et al., 2000; Turner et al., 2002). Recently, changes in concentrations of various nutritional components have been related to heating characteristics within large round bales in regression relationships that often are curvilinear, and frequently exhibit asymptotically defined limits in severely heated hays (Coblentz and Hoffman, 2009b; Coblentz et al., 2010). These general characteristics were corroborated in the present study. However, regression relationships for several nutritional components within acidtreated hays (specifically, $\Delta \mathrm{NDF}, \Delta \mathrm{LIG}, \Delta \mathrm{ASH}, \Delta \mathrm{CP}$, and $\triangle T D N$ ) exhibited more inflection points or were higher-ordered polynomial regressions than those of corresponding control hays. This may have been related to the perturbation of normal heating patterns within acid-treated hays; as discussed previously, HDD generally were accumulated at decreased MAX, but over a longer duration of time.

The interactive responses for $\triangle \mathrm{NDICP}, \triangle \mathrm{ADICP}$, and $\triangle$ HEMI as functions of HDD were unique. Although slowed somewhat in response to acid treatment, $\triangle$ NDICP increased rapidly with only modest heating in all hays, and reached asymptotically defined limits at about 360 and 967 HDD for control and acid-treated hays, respectively. As defined by these nonlinear regression curves, respective maximum values for $\triangle \mathrm{NDICP}$ were 29.8 and 28.7 percentage units of $\mathrm{CP}$, which sug- gests that NDICP accounted for almost half of the total forage CP in modest-to-severely heated hays (Table 4). In contrast, $\triangle \mathrm{ADICP}$ increased more slowly, especially with minimal heating, but exceeded 25 percentage units of $\mathrm{CP}$ within severely heated hays. For these most damaged hays, this accounted for more than $80 \%$ of the increases observed for $\triangle$ NDICP. Previous studies have shown that ADICP increased linearly with HDD in small square bales of alfalfa (Coblentz et al., 1996) and bermudagrass (Coblentz et al., 2000; Turner et al., 2002), but increased more rapidly in large round bales of alfalfa-orchardgrass hay incurring far greater HDD (Coblentz et al., 2010). In that report, $\triangle \mathrm{ADICP}$ was related to HDD with the same nonlinear model observed for acid-treated and controls hays in the present study (Table 4). In these studies with large round bales, $\triangle$ ADICP increased slowly with modest heating $(\sim 500$ HDD), but more rapidly thereafter. This accelerated response for $\triangle \mathrm{ADICP}$ with greater HDD coincides with the apparent reactivity of hemicellulose. Presumably, hemicellulose decreases in response to severe heating because it becomes reactive, and plays an important role as a reactive carbohydrate in Maillard reactions; subsequently, it is no longer recovered as hemicellulose, but it is recovered as artifact lignin (Goering et al., 1973; Van Soest, 1982).

Concentrations of TDN $(\triangle T D N)$ decreased by as much as 20 percentage units in severely heated hays (Table 4), which represents an enormous energy loss from the forage. Historically, educational programs for producers have focused on describing the effects of heating on subsequent ruminal protein availability. Although quantifying $\triangle \mathrm{ADICP}$ remains an important consequence of poor hay production management, it belies huge losses of energy, which are at least as important.

\section{CONCLUSIONS}

Although acid treatment clearly perturbed normal patterns of heating within large round bales, our applications of the propionic acid-based preservative resulted in only limited improvements in post-storage nutritive value, relative to controls. Although the potential exists to apply preservatives at greater rates, the practicality of this approach is questionable. With our field equipment, greater rates would likely require increased time to form each bale that could be achieved through slowing ground speed or baling single-raked windrows. However, spray attachments are normally mounted directly above the pick-up attachment on large-round balers, and the preservative is applied across the entire width of the baler pick-up. Increasing the calibrated application rate with less-restrictive nozzles, or limit- 
ing the quantity of hay entering the baler both would likely increase waste. Furthermore, it becomes difficult to increase percentage-based application rates in wetter hays because actual bale weights increase concurrently. Given current prices, the application rate used in this project would add approximately $\$ 10$ of additional cost per bale, thereby exceeding $\$ 15 /$ ton (imperial ton) for most practical field applications. Relative to large or small square bales, large round bales have inefficiencies with respect to stacking, hauling, and incorporation into blended diets; as such, they do not generally fill value-added niches of any type, and the cost of acid application could easily exceed $15 \%$ of the value of the bale. Furthermore, bales made for these studies were stored outdoors in a manner that would easily allow water to dissipate from the hays. It remains unclear how these results may have been altered by tight packing within an enclosed barn or shed.

Past studies have demonstrated clear benefits from application of propionic acid-based preservatives during packaging of small square bales of alfalfa hay, and similar responses also have been observed recently at our station within $(275-\mathrm{kg})$ large square bales (W. K. Coblentz, unpublished data). However, results obtained from this study with large round bales were much less favorable. This could be related to the greater size of the bale packages, differences in application methodologies between round and square (plunger-type) balers, or other factors. It also remains unclear whether results might have been more favorable if bale diameter had been decreased. Regardless, the potential for improving nutritive value relative to cost for these very large (1.5-m diameter) round bale packages is not especially favorable. Producers may find that diligence to achieve adequate field desiccation before baling $(\sim 15 \%$ bale moisture; Rotz and Muck, 1994), or use of oxygenexclusion methods, such as wrapping in plastic, may be better alternatives for preserving moist hays baled in large round bale packages.

\section{REFERENCES}

AOAC. 1998. Official Methods of Analysis, AOAC Official Method \#990.03. 16th ed., 4th rev. Association of Official Analytical Chemists, Gaithersburg, MD.

Buckmaster, D. R., and A. J. Heinrichs. 1993. Losses and quality changes during harvest and storage of preservative-treated alfalfa hay of varying moisture content. Trans. ASABE 36:349-353.

Coblentz, W. K., J. O. Fritz, K. K. Bolsen, and R. C. Cochran. 1996 Quality changes in alfalfa hay during storage in bales. J. Dairy Sci. 79:873-885.
Coblentz, W. K., and P. C. Hoffman. 2009a. Effects of bale moisture and bale diameter on spontaneous heating, dry matter recovery, in vitro true digestibility, and in situ disappearance kinetics of alfalfaorchardgrass hays. J. Dairy Sci. 92:2853-2874.

Coblentz, W. K., and P. C. Hoffman. 2009b. Effects of spontaneous heating on fiber composition, fiber digestibility, and in situ disappearance kinetics of neutral detergent fiber for alfalfa-orchardgrass hays. J. Dairy Sci. 92:2875-2895.

Coblentz, W. K., and P. C. Hoffman. 2010. Effects of spontaneous heating on estimates of total digestible nutrients for alfalfaorchardgrass hays packaged in large round bales. J. Dairy Sci. 93:3377-3389.

Coblentz, W. K., P. C. Hoffman, and N. P. Martin. 2010. Effects of spontaneous heating on forage protein fractions and in situ disappearance kinetics of crude protein for alfalfa-orchardgrass hays packaged in large round bales. J. Dairy Sci. 93:1148-1169.

Coblentz, W. K., J. E. Turner, D. A. Scarbrough, K. E. Lesmeister, Z. B. Johnson, D. W. Kellogg, K. P. Coffey, L. J. McBeth, and J. S. Weyers. 2000. Storage characteristics and nutritive value changes in bermudagrass hay as affected by moisture content and density of rectangular bales. Crop Sci. 40:1375-1383.

Collins, M., W. H. Paulson, M. F. Finner, N. A. Jorgensen, and C. R. Keuler. 1987. Moisture and storage effects on dry matter and quality losses of alfalfa in round bales. Trans. ASAE 30:913-917.

Goering, H. K., P. J. Van Soest, and R. W. Hemken. 1973. Relative susceptibility of forages to heat damage as affected by moisture, temperature, and pH. J. Dairy Sci. 56:137-143.

Jafri, S. A., L. J. Bush, and G. D. Adams. 1979. Chemical preservation of alfalfa hay for dairy cows. J. Dairy Sci. 62:455-458.

NRC. 2001. Nutrient Requirements of Dairy Cattle. 7th rev. ed. National Academy Press, Washington, DC.

Rotz, C. A., R. J. Davis, D. R. Buckmaster, and M. S. Allen. 1991. Preservation of alfalfa hay with propionic acid. Appl. Eng. Agric. $7: 33-40$.

Rotz, C. A., and R. E. Muck. 1994. Changes in forage quality during harvest and storage. Pages 828-868 in Forage Quality, Evaluation, and Utilization. Proc. Natl. Conf. on Forage Quality, Evaluation, and Utilization, Lincoln NE. G. C. Fahey, Jr., M. Collins, L. E. Moser, and D. R. Mertens, ed. ASA, CSSA, and SSSA, Madison, WI.

SAS Institute. 1990. SAS/STAT: User's guide. Version 6, 4th ed. SAS Inst. Inc., Cary, NC.

Sheaffer, C. C., and N. A. Clark. 1975. Effects of organic preservatives on the quality of aerobically stored high moisture baled hay. Agron. J. 67:660-662.

Shinners, K. J. 2000. Evaluation of methods to improve storage characteristics of large square bales in a humid environment. Appl. Eng. Agric. 16:341-350.

Turner, J. E., W. K. Coblentz, D. A. Scarbrough, K. P. Coffey, D. W. Kellogg, L. J. McBeth, and R. T. Rhein. 2002. Changes in nutritive value of bermudagrass hay during storage. Agron. J. 94:109-117.

Van Soest, P. J. 1982. Nutritional Ecology of the Ruminant. Cornell University Press, Ithaca, NY.

Van Soest, P. J., J. B. Robertson, and B. A. Lewis. 1991. Methods for dietary fiber, neutral detergent fiber, and nonstarch polysaccharides in relation to animal nutrition. J. Dairy Sci. 74:3583-3597.

Weiss, W. P., H. R. Conrad, and N. R. S. Pierre. 1992. A theoreticallybased model for predicting total digestible nutrient values of forages and concentrates. Anim. Feed Sci. Technol. 39:95-110. 